\title{
A Snapshot of the Roles of Knowledge in the New
}

\section{Times}

\author{
Chi Hong Nguyen \\ 17 Hardgrave Road, West End, Qld. 4101, Australia \\ E-mail: nguyenhongchi@yahoo.com
}

Accepted: Feb 17, 2013 Published: March 18, 2013

Doi:10.5296/jsr.v4i1.3392ＵRL: http://dx.doi.org/10.5296/jsr.v4i1.3392

\begin{abstract}
Globalization involves the reconfiguration and restructuring of capitalist organizations where knowledge becomes the main resource for effective production, forming a knowledge-based economy in the new times. The article analyzes recent educational literature on the knowledge-based economy with a discussion on types of necessary knowledge which nurture students' thinking ability in order to possibly enhance their life-long learning ability which is considered as important for individuals in the knowledge economy to proactively enter the global integration process. This essay proposes that by playing the key role in production in the knowledge economy, knowledge is also deemed as a competitive factor for economic growth and as social capital for individuals to live and work. As knowledge takes a newer role compared to the traditional understanding of knowledge as the remembering of separate facts, educational sectors are now tasked with more responsibilities in producing a responsive and intellectual workforce to live and work well in the global integration time.
\end{abstract}

Keywords: Globalization, Knowledge, Knowledge-based Economy 


\section{Introduction}

Since the very early time of feudal and colonial invasions in terms of politics, economy as well as culture, national borders have been permeable although sovereignty and identities are strongly maintained. Emerging as a modern multidirectional form of spatial and time reduction, globalization is said to be occurring in many parts of the world where peoples "are incorporated in a single world society, global society" (Albrow \& King, 1990, p. 9). With the advancement in transportation, information technology (IT), and telecommunications, globalization means just more than the common perception that the world seems to shrink into a global village. In fact, globalization involves the reconfiguration and structuring of capitalist organizations (Brenner, 1999 cited in Yeung, 2001, p. 2) where knowledge becomes the important factor for effective production and the key indicator in economic competitiveness, forming a knowledge-based economy in the new times.

In practice, the knowledge economy has actually emerged in North America and West European countries, accounting for $45-50$ per cent of their GDP, and more than 50 per cent of GDP in OECD countries (Bao Buu dien Vietnam, 2003; Do, 2003; OECD, 2001). Due to the emerging role of the knowledge economy, a set of workplace competencies is proposed to include interpersonal, intrapersonal and technological skills to meet the demands for a new workforce in the new times. In general, knowledge workers have a high level of education and literacy which is usually in the form of certified knowledge (OECD, 2001). However, under the forces of globalization which bring different countries and individuals to a closer spatial and time network, the new workforce needs more tacit skills than the proposed set of definite skills as mentioned above. The workplace competencies function in alignment with the adoption of new work practices in firms which requires the ability of abstraction, system thinking and collaboration skills (Reich, 1991). In other words, the knowledge economy requires individuals to possess a new set of knowledge, and an investigation of current views of knowledge in the knowledge based economy is the main focus of this essay.

From a micro view at firm level, the knowledge economy can be characterized in terms of the increasing role of knowledge as the main factor of production which also shapes changes in organizational structures and individuals' career paths, but this essay is not going to discuss these organizational changes in detail. Instead, it aims to analyze the role of knowledge as social capital for knowledge workers to obtain. In fact, thanks to the advancement in IT and new technologies, science becomes the direct production force, and production time can be shortened. As a result, there is an increase in the codification of knowledge which encourages a radical change in organizational structures and operations. Further, this codification of knowledge produces a convergence, bridging different components of professionalism, competence and knowledge (Houghton \& Sheehan, 2000). Learning concurrently becomes necessary for people who need more practical types of learning such as learning-by-doing, learning-by-using and learning-by-interacting. Simply put, human knowledge as cultural and social capital plays an important role as an engine for economic growth in a country (Thant, 1999), and the questions about what knowledge is with regards to its roles in economic 
growth and competition, how to best foster the accumulation of knowledge for each individual's career benefits, and how to apply it effectively at work always occupy an important place in academic discussions on social development.

\section{Knowledge as a competitive factor in the new economy}

The scientific revolution and its establishments which emerged in the 1950s have urged the proliferation and expansive applications of computers with a widespread use of the Internet, and of transportation. They have all created dramatic capabilities to remake the nature of different professions, workplace relationships and economies in which the use of knowledge has increasingly become vital and central to economic growth (Lin, 2006; Walter \& Snellman, 2004). The knowledge-based economy or the knowledge economy is commonly defined as the economy in which production and services are based on knowledge-intensive activities that are geared to an accelerated pace of technological and scientific achievements, and the production and exploitation of information and knowledge are deemed as a prerequisite for the creation of wealth (OECD, 1996). In fact, according to Machlup's (1962) analysis, knowledge was found to account for around 29 per cent of GNP in knowledge-production in knowledge industries during the earlier decade of the knowledge economy, and this ratio has increasingly amounted to more than half of the GDP in OECD countries nowadays (OECD, 1996).

The main components of a knowledge economy consist of a stronger dependence upon human capital than on physical resources or inputs, and more improvements in production stages. These transitions are normally indicated in a country's GDP that is closely linked to intangible capital (Abramovitz \& David, 1996). Since then, a multitude of macroeconomic research has started to look into the core role of knowledge in its contribution to a country's wealth and examined the centrality of knowledge as a driving force for innovations which led to the new growth theory, which briefly states that human desires and wants may urge more economic productivity and pushes economic yields, and thus the economic growth encourages more competition which in turns forces us to seek more efficient and innovative methods for higher profitable production (Romer, 1986). From a microeconomic view, recent research has placed a strong focus on the changes in the nature of jobs and the role of life-long learning and continuous innovation abilities inside firms (Drucker, 1993; Kochan \& Barley, 1999). Simply put, knowledge is considered as power, and the ability to produce and use knowledge effectively is an important skill for many individuals. As a result, human capacity building is critical in the knowledge economy as it can yield social and personal returns for social progress (Schultz, 1963). The production of knowledgeable workforce will create the main pillars for a knowledge economy.

In a knowledge economy, production is dependent upon physical resources, capital, labor and knowledge. According to Pham (2006), while the other factors can be mobilized in a limited extent, human knowledge seems unlimited and unlikely to be measured quantitatively, especially when it is reflected and resides inside the inseparable components of products we consume. It is common that knowledge accumulation is measured via patents and formal 
qualifications which in turn have a price. These papers are normally purchased by consumer-producers or employers who from time to time do not possess that particular kind of professional knowledge in order to apply in their production processes. In fact, knowledge which is seen as a commodity or an asset of an organization can also be a production material for another. Every product is always gone through a set of different manufacturing processes which involve knowledge with its added value. These processes may be considered as a labor process in which human cognition and meta-cognition exceeds such skills as dexterity and physical strength. Knowledge then becomes both a form of labor and an intangible asset that capitalist organizations can mobilize in the market. In other words, knowledge plays the role of a tool that firms use to acquire an efficient form of labor, and it facilitates a new work model.

As being too vast and unlimited, knowledge is definitely not a destination that should be fully grasped feasibly. On the contrary, the ultimate goal of a knowledge economy is to increase productivity and efficiency via an increasing use of knowledge since every stage of production and stage of life includes a diffusion of knowledge. The knowledge-based economy is not necessarily the one in which high technologies must be manufactured in lieu of agricultural and industrial products as we always need food to live, but not high technologies to eat. Take Pham's (ibid.) interesting example about the role of knowledge in agricultural production, farming would remain a traditional pursuit in Vietnam which accounts for 57 per cent of the total workforce and has made it the world's second largest rice exporter. However, farmers could earn bigger harvests with the assistance of information on weather forecast and scientific guidance from biochemical experts. Such a transition from an industrial economy to a knowledge economy does not eradicate human basic needs. As a consequence, on the one hand, it is found that an increase of knowledge can proportionately increase economic productivity, but on the other, such a vast increase in the unlimited stock of human knowledge does not explicitly reflect an increase in values and income or completely change one's life. In this vein, choosing what to know and how to use it at a later stage should be seen as a more central task for knowledgeable workers. Human knowledge, since the beginning of time, has been too large for any individual to ingest. This is why von Hayek (1945) is resonant by saying that economic studies are not only concerned with the equal allocation of resources but also consider how to guarantee the best use of knowledge and the utilization of knowledge which is not given to us in its totality. Different individuals should be ensured that they know what to learn and how to exploit what they have known, though what is known always remains limited and partial, to cooperate and compete with others in society. As such, the practical usage of knowledge is not to strive hard to enlarge their personal knowledge body in a variety of aspects and professions, but is to deepen what has been known. From a macro-level, such interactions amongst different individuals in the market may lead to a further creation of knowledge, and the expansive discovery of the unknown will create a stronger competitive edge for a country.

\section{Knowledge as social capital for individuals in the new times}

From a micro-level, one of the emerging features of the knowledge economy is the creativity for one's survival and competition (Tran, 2002). Existing scientific advancements will create 
new knowledge which will produce new technologies. The two of them play a co-existent role in forming the competitive advantage of products and exports. Such a process of economic creativity usually includes a launch of a new product, an improvement of an existing product with new qualities, an application of new and efficient methods of manufacture, a creation of a new market with targeted customers, a creation of new materials and by-products, and a change in organizational structures (ibid.). Innovations from research and research and development (R\&D) activities become central to economic growth. Therefore, the generation of wealth normally depends on the discovery of the unknown and the improvement of the known toward another dimension of the unknown. However, according to Lin (2006), human present knowledge is analogous to an inherited and accumulated asset from past generations which can be metaphorically seen as "a knowledge barn" (p.328), which is occasionally considered as a fictitious commodity with a shared and exchanged value (Jessop, 2007). On the one hand, it is reasonable that in the time of globalization when countries and groups of people come nearer thanks to the achievements of telecommunications and transportation, human knowledge is likely to be seen as international public goods which can spread across borders and different groups of people in different localities and ages. On the other, the discovery of knowledge and the newly found will cause a wider gap between those who are able to gain access to a better education and research infrastructure and those who are not, and between developed countries and developing countries in the new times.

According to Limerick, Cunnington and Crowther (1998, pp. 4-5), "the new times" extend back to the 1980s when the world began to experience different major changes in economic, political and social aspects. In fact, the set of issues happening in the 1980s is not the same as that of the 1990s which is, in turn, not similar to that of the 2000s. The differences form a "paradigm of discontinuous changes" where even change even turns to be changeable itself (Bennis \& Nanus, 1985, p. 8; Law \& Glover, 2000, p. 127; Limerick, Cunnington, \& Crowther, 1998, pp. 4-5). Furthermore, change is a non-linear process, and it cannot always be easily managed or created (Kirkbride, Durcan \& Obeng, 1994). The past and present cannot always prepare us for the future in a proper manner. In addition, it is obvious that advances in transportation, information technology (IT) and communications have brought to countries both opportunities and threats which can be considered as the dark sides of this third technological revolution. Human beings have experienced the new times comprising of various interrelated changes on a global scale, so the ability to handle chaos and risk proactively is the required quality that they should acquire to survive and develop healthily. In addition, national borders have turned to be more permeable and fragile when globalization as a process or a set of processes includes a spatial transformation in the organization of social relations and transactions (Held, McGrew, Goldbaltt, \& Perraton, 2000). Consequently, this new time of discontinuity urges people to come together to deal with the issues and their impacts by utilizing their own knowledge, a giant power and a dominant resource of prosperity and well-being (Marginson, 1999; Nguyen, 2000). In other words, knowledge is seen as a necessary and sufficient condition for people in the new times to live and work effectively (Phan, 2000). The new times with full of changes and unpredictability are now upon us, but what kind of knowledge is deemed necessary for our survival and 
development? This question is not easy to answer because as stated earlier, human knowledge is vast with different types in both social and professional aspects. Yet, the ways to obtain knowledge for practical usages are different from those in the past.

Knowledge is traditionally defined as the remembering of previously learned material or the body of truth, information, and principles acquired by humankind or interpreted information that can be used. This may involve the recall of a wide range of material, from specific facts to complete theories, but all that is required is to possess a great memory capacity to memorize a stock of information. Burton-Jones (1999) defines knowledge as the accumulation of information and skills derived from use of information by the learner. More particularly, Nelson and Winter (1982) (see also Lamberton, 1997; Stevens, 1998; Tomassini, 2001) distinguish two different kinds of knowledge: tacit and codified knowledge. Tacit knowledge is living knowledge that resides in the head of an individual, and its transfer is extremely sensitive to social contexts. Codified knowledge, as a term, means the use of a written language or symbols to encode the knowledge of other people, which can then be reduced to information. Codified knowledge is easily transferable in information and can be transmitted through IT and media over long distances and across organizational boundaries. Codified knowledge is often transferable and can be articulated to other people while tacit knowledge is embedded and resides in one's head. As Polanyi (1966) notes, tacit knowledge is the known that we may sometimes be unaware; or to put it simply, we may know more than what we know.

As mentioned earlier, knowledge is the key strategic resource for any firms to exist, compete and develop in the new times though it has been too hard to define exactly what it is since a long time ago (Grant, 1996). Therefore, if used properly, tacit knowledge will become more strategically significant because rivals may find it hard to replicate, and similarly the firm itself will find it difficult and challenging to exploit the tacit knowledge within their organization if their workers are not given an opportunity to perform their tacit knowledge, or if they do not have sufficient infrastructure or encouragement to show their talents. According to Nonaka, Toyama, and Hirata (2008), the accumulation of knowledge is like a process where knowledge is not only about knowing but that knowing act also influences and is influenced by the surrounding environment. This is why a supportive workplace environment plays an important role in the application and exploitation of both tacit and codified knowledge. When their tacit and codified knowledge is in use, individuals may earn more practical knowledge in the form of wise experiences through the learning and working process. Therefore, practical knowledge plays a major role in an effective use of knowledge in addition to universally valid and scientific knowledge and technical knowledge. Both codified and tacit knowledge, which may reside in the form of practical knowledge, becomes the valuable resource which is likely to change as learning happens when one desires to discover what is unknown to them. In other words, besides being an exchangeable commodity, both tacit and transmitted knowledge can also evolve when internal learning happens through the working process, and it will create more social capital for competition and survival for its possessors, namely knowledge workers. 
Within the new times, different individuals in different workplaces and networks often mutually interact in their daily work, and such networks and interpersonal relationships will foster the resources in forms of both tacit and codified knowledge in these relationships, and thus enhance their social capital (Bourdieu, 1997; McFadyen \& Cannella, 2004). This kind of capital will influence the knowledge exchange process and provide an accessible form of resource network which will help further enhance the discovery of the unknown among the network members with regards to its exchanged and shared feature. Social capital includes both interpersonal relationships and the resources entailed in such relationships (Burt, 1992) with which each member is able to get access to the knowledge stock of others, although this knowledge share and creation always comes with a cost of time to establish and maintain the relationships, money for collaborative research, and also sympathy. This knowledge creation process will help each member accumulate and enrich their knowledge as social capital which resides in each of the members.

However, acquiring this kind of social capital poses some challenges for network members. First, due to one of the characteristics of globalization as flows or movements of people, ideas and goods (Appadurai, 1996; Christie \& Sidhu, 2002; Waters, 2001), knowledge can also be transported through IT, telecommunications, and the mobility of academic staff and students. IT and global communications technologies, on the one hand, make knowledge available to those who have access to them. On the other, national and international laws on copyrights and intellectual property make it hard to retrieve information. Also, as Marginson (1999) aptly puts it with regards to education, these technologies facilitate the growth of market exchange in which education is defined as a corporate service that must obey the economic laws of supply and demand. IT and communications technologies speed "the translation of knowledge into transmittable information", so knowledge becomes "saleable commodities" (p. 21). As such, the knowledge economy can widen the "social inequality" and "social exclusion" (Castells, 2000, p. 68), or as in Marginson's (1999, p. 28) terms, "access and exclusion", between the have and the have-not in the sense that the latter become unable to acquire sufficient education to obtain "cultural capital" (Bourdieu, 1997, p. 49) which can be used to compete for their "social status" (Marginson, 2004, p. 181). As a result, education sectors are now charged with authentic tasks to meet such a demand for the new times' workforce, and the section below will outline some major realities regarding the changes in common perceptions about knowledge that education is currently supposed to take into account.

\section{New realities facing education in the knowledge economy}

According to Lundvall and Johnson (1994), knowledge can be understood as a broader term than information which includes only the know-what (referring to facts) and the know-why (referring to scientific principles and laws of nature), all of which are normally learnt from books, lectures at university, or available databases. Other kinds of knowledge such as the know-how (skills and ability to do things) and the know-who (involving information about 
who knows what and who knows how to do what) become increasingly necessary for the management of change in the new times. The know-who and the know-how require practical experiences and social practices. IT and telecommunications developments which encourage the process of codifying certain types of knowledge can respond to the demand of handling the know-what and the know-why more effectively. As a result, knowledge can be codified and transmitted over long distances and across many time borders, creating an information society where "a majority of workers will soon be producing, handling and distributing information or codified knowledge" (OECD, 1996, p. 13). However, due to such an IT burgeoning development in forms of open Internet sources, there are also many slanderous, inappropriate and unreliable sources of information that have not been properly controlled, researched or assessed. Therefore, information and truths may be distorted because of personal jealousy or severe competition between groups of net-citizens (Friedman, 2005). Further, plagiarism is an unavoidable drawback of the information society when some un-established academics who have quick and easy access to information are tempted to violate academic rules and ethics to reproduce and copy works and research results done by other previous professionals without acknowledging the original authors. Therefore, learners and knowledge workers, in general, must train necessary ethical conducts in doing research to appropriately approach, retrieve and use information that will be absorbed and formed as their long lasting knowledge. An awareness of being an ethical researcher or independent learner should be increased and nurtured to produce capable knowledge producers for the future if knowledge workers wish to increase and use their knowledge as social capital for long.

In addition to technical knowledge, many other skills are also identified as necessary for knowledge workers in the new times. A long list of skills seems endless, but some are dominantly mentioned such as functional and adaptive skills, personal traits, collaboration and teamwork (Murphy \& Jenks, 1983; OECD, 2001), basic literacy skills, responsibility, and motivation (Junge, Daniels, \& Karmos, 1984). All seem too well-rounded for anyone to acquire all in reality, and this is the reason why potential knowledge workers must be able to realize what they really want to do for their professional life, why they want it, and how they can achieve it besides the academic knowledge obtained from formal education. Education is then supposed to train citizens a whole range of living skills and social knowledge to enter and take advantage of the process of global integration in addition to the teaching of foreign languages (English), mathematics (statistics and probability), and computer literacy. Furthermore, education must, on the one hand, produce and maximize conditions for students' learning (Christie \& Lingard, 2001; Lingard, Hayes, Mills, \& Christie, 2003) to be able to realize and nurture their ability and to deal with unpredictability. Further, as there are more widening gaps in terms of economics and knowledge accumulation caused by globalization as briefly mentioned earlier, educational institutions need to be aware of social inequalities or the questions of "access and exclusion" (Marginson, 1999, p. 28), which they cannot always compensate for. Educational sectors must reduce as many disadvantages as possible by providing students with two kinds of knowledge to enter the world: social and academic. Social learning builds up students' consciousness of their citizenship and civic 
participation, and academic learning helps engage them in understanding and applying different kinds of knowledge critically and analytically.

Today's demands to learn to use technologies and to produce new knowledge are prominent. Answers to "What?" and "Why?" can be found in the media, lectures and databases. Answers to "Who must do what?" and "How to do?" originate from learners' real needs to explore and to apply that kind of knowledge into their work and lives. Singapore may well be taken as an example of educating their citizens with creativity and learning motivations via their governmental project "Thinking Schools, Learning Nation" (Singapore's Ministry of Education, 2007). The Singaporean State has mandated and invested their universities and high schools to design pragmatic, interrelated and interesting curricula. Textbooks, teachers and the whole educational system do not solely act as a machine certifying students' knowledge, but they are employed as devices which help students gain knowledge to use in their lives. Singaporean teachers have to renovate their traditional ineffective teaching methods from monologue lecturing styles to learner-centeredness. The main philosophy of this project is to educate students the ability to think logically and analytically, to study independently, and to be able to become critical. This ultimate goal is to produce future capable knowledge citizens an engine for national growth. Therefore, educating learners with positive learning attitudes becomes increasingly significant in modern pedagogies. There needs to be more reform efforts in improving out-of-date and ineffective teaching methods. Innovative teaching strategies such as case-studies, learner-centeredness, teaching methods based on learners' demands, and learning by discoveries can enhance students' intrinsic motivations and encourage them to discover new information, disseminate human knowledge and produce new knowledge. As a matter of fact, this project is one of the measures taken to reform the education system in order to assist the national development process. The project "Project-Based Learning" has been conducted nationwide at elementary and secondary education since 2000, and this project is regarded as an important strategy which has had a great and practical contribution to "Thinking Schools, Learning Nation".

The primary objectives of the "Project-Based Learning" Project are to enhance the interconnection between school subjects, to help students discover mutual relationships in the knowledge received at high school. Situation-based learning helps students practice creative and critical thinking skills, and improve their communication skills, strengthen their cooperation in studies, and develop their independent learning ability and their lifelong learning desire. More specifically, the "Project-Based Learning" focuses mainly on four aspects: (1) applying the knowledge when students are able to perceive and create the links among the fields of knowledge, to develop and evaluate information and apply it into their own situations; (2) communication skills with which students are able to speak and write fluently, present their ideas effectively, precisely and coherently; (3) cooperative and teamwork skills; and (4) independent learning skills. Simply put, students should be taught different strategies to acquire knowledge and learn to appreciate the usefulness of knowledge application rather than merely learn to become a walking encyclopedia that unwittingly digests knowledge. Although this project and its trajectories may not well be replicated in 
other settings due to the differences in demographic, cultural, social and political systems, such lessons from its objectives could be learned to maximize students' outcomes in social learning and prepare for the ability to handle change in the new times.

In terms of change management in the new times, according to Nguyen (2010), higher education is now tasked with the responsibility to produce and disseminate knowledge for society, and is supposed to train students with the ability to become prospective independent researchers in many aspects of profession such as doing action research in their everyday work lives or even in nation-scale projects. Traditional education goals which consist of cognitive, affective, and psychomotor learning (Bloom, Mesia, \& Krathwohl, 1964; Linn \& Gronlund, 1995) must remain as one of the central tasks of education in the new times, but it is required to produce a more responsive intellectual workforce who can thrive and live well in a constantly changing environment (Seltzer, 1996). As Nguyen (2010) and Schon (1995) argue, academic knowledge or school knowledge reflected and embedded in curricular, being rooted in the mind of teachers, and communicated by instructions to students is not sufficient. Instead, knowledge in the new times must be built around a socio-constructivist conception of knowledge which is academic, social-related, practical and critical. This kind of knowledge should also be shared on a collaborative basis and constantly questioned, assessed, transformed, and managed scientifically.

To achieve the target of providing this social and academic knowledge, Proenza (2000, p. 2) emphasizes that in the increasingly complex and interdependent world, finding solutions to certain problems requires "shared knowledge and understanding, and also shared commitment among all peoples of the world." The task of knowledge production is now reliant on the shoulders of higher education sectors, research institutes and lecturers. Unfortunately, this issue poses a challenge for developing countries as they often lack already-established knowledge and highly skilled human capital, sufficient infrastructure, R\&D abilities, institutional support, and even technopreneurs (Govindan, 2000). For example, Vietnam has been facing a serious lack of lecturers and professors at universities in quantity and also in quality. The average ratio of lecturers over students is 1/50 (Educational Statistics, 2009; Nguyen, 2000). Lecturers are now being exploited with full schedules of teaching at a university from seven to nine o'clock in the morning and then another class at ten another university. The same timetable is compulsorily applied in the afternoon and even in the evening at a continuing-education (in-service) centre. It is definitely difficult for them to improve their specialization through doing research or attending a formal professional development course. Furthermore, the small percentage of qualified lecturers at tertiary level also confronts the Vietnamese Government in enhancing the quality of their tertiary education provision. Indeed, the number of highly qualified professionals such as professors, associate professors, doctors, and masters accounts for less than ten per cent of the population (Educational Statistics, 2009). From 1980 to 2009, there have been 1336 professors and 7062 associate professors nationwide (The State's Professorship Selection Board, 2010) out of the total population of 82.6 million (Duong, 2009), and many of them are in the age of retirement. This is an alarming situation for Vietnam to enter the global economy in such a marathon 
with other developed countries as knowledge is viewed as a competitive factor for a nation's economy.

Knowledge has been important to economic growth, and knowledge workers become the modern source of economic growth and development (Drucker, 1994; Duffy, 1997; Straubhaar, 2001). The development of biotechnology, outer-space industry, new material technology, information and communication technologies and particularly the Internet, which are commonly considered as the main pillars of the knowledge based economy, has enabled the formation of the knowledge economy by breaking down barriers to knowledge and participation in knowledge production. The knowledge economy is emerging from "the rise in knowledge intensity of economic activities and the increasing globalization of economic affairs" (Houghton \& Sheehan, 2000, p. 2). The knowledge based economy is directly based on the production, distribution and use of knowledge and information (OECD, 1996), and the APEC Economic Committee also emphasizes that in a knowledge-based society the production, distribution and use of knowledge are the main driver of growth, wealth creation and employment across all industries (APEC, 2000). In an agricultural economy, land is the key resource. In an industrial economy, natural resources and labor are the main resources. In the knowledge economy, knowledge and the effective use and exploitation of all types of knowledge in all manners of economic activities are considered as the key resources (DTI, 1998). In a knowledge economy, agriculture and industry do exist, but they entail an application of information and scientific knowledge in the production. New industries like IT, new service industries based on high-tech achievements or even traditional industries are reformed by new scientific inventions, creating "the third industrial revolution" - the information revolution supported by the widespread use of computers and high technologies (Thurow, 1999 cited in Iredale, Guo, \& Rozario, 2003, p. 1). The uses of high-tech industries will in turn enhance the production of agriculture and basic industries. Therefore, education is now supposed to work in a close collaboration with agricultural, industrial and informational production. In other words, education is placed within its social development, and in turn it may affect social network and production in the postindustrial society.

According to Castells (1999), during the first half of the $20^{\text {th }}$ century, science and technology were considered as the main sources of productivity. However, since the post-World War II and especially the post Cold War periods, knowledge and information have played a determinant role in generating wealth and power in the postindustrial society where production modes have been altered from the goods-production to service-oriented approach. Yet, the rise of "informationalism" is always intertwined with "inequality and social exclusion" which exist amongst individuals, groups and nations (Castells, 2000, p. 68). Indeed, there is always a great gap between developed and developing countries where in the latter the knowledge based economy has not been able to completely replace the traditional economy whose main production resources are labor, capital, land and physical infrastructure (Do, 2003). Further, not everyone, especially those in developing countries, is provided with comfortable and available access to information. Even in informational capitalism, poverty, polarization of the rich and the poor, and over-exploitation of workers still exist, hindering disadvantaged 
individuals and groups from getting access to "an autonomous livelihood" (ibid., p. 71). In this vein, according to Foucault (1977), knowledge and power are mutually constitutive in the sense that knowledge produces power, and so does power. In his Discipline and Punish, Foucault (ibid.) asserts,

$\ldots$... TThere is no power relation without the correlative constitution of a field of knowledge, nor any knowledge that does not presuppose and constitute at the same time power relation ( $\mathrm{p}$. 27).

In fact, knowledge enables individuals and groups to acquire "expert power" which may help them obtain "position power" with the right to exercise influence due to their special expertise and position (Law \& Glover, 2000, p. 33). Power, which can be used to legitimize knowledge, also secures individuals' positions and creates more convenient access to "resource power" (ibid.) which can be used to produce more knowledge. In other words, it is inevitable that inequality occurs between elites (advantaged groups) and ordinary workers and laborers (disadvantaged groups) in almost any place in this world. This essay is not trying to discuss what educational leaders and scientists should do, but it aims to highlight such an inequality that exists in all forms of capitalist work settings that students should be able to know about and to be taught ways to minimize its effects in their professional lives.

In addition, since the past two decades, the widespread application of IT has connected people from parts of the world together to share knowledge. Information becomes the most important resource in the new times. Those who have access to IT can retrieve the information they want within a fraction of a second. Many economic activities can be completed through the Internet. Yet, this phenomenon creates a big gap between the have and the have-not. In fact, although the number of worldwide Internet users has been increasing recently from 159000 in 1989 to 43 million in 1999 (Houghton \& Sheehan, 2000, p. 2), the number of those who can get access to the Internet in Vietnam in a global survey in 2000 was 130000 , accounting for only 0.022 per cent of the total worldwide population online (Globalization Guide, 2000). Governments in developing countries like Vietnam then have to consider their funding to the building and development of IT as one of the top priorities in their strategic plans. Nevertheless, it is difficult for those in authority to filter and stop the flows of information that harm their national development plans and distort their political ideologies. As a consequence, the development of IT and the Internet causes another challenge to governments in cultural aspects. Owing to the permeable invasion of foreign cultures, their national and traditional identities are more likely to become a hybrid type or lose their own identities. Facing the lack of IT infrastructure together with the duty to remain and encourage the national identities are the double task for those in authority and education to complete in the new times.

Finally, because education becomes the top priority for people to develop their professional and social ranking, this priority for educational development constitutes a learning society where people can expectedly learn for their whole lives at anytime and anywhere. Nevertheless, creating an equal chance in education for everyone is a challenging task in developing 
countries where there is a lack of necessary infrastructures and state funding as mentioned previously. It is wondered what poor people need to do first as a priority in their daily lives: whether it is how to make money to buy food or whether it is time to go to school with an empty stomach. Around 1.2 million people live on less than one dollar a day, and over three billion people live on less than 2.50 dollars a day, while a burger may cost around four dollars (Poverty Facts and Statistics, 2005). As a result, this leads to unequal scholastic achievement which causes trouble to those from disadvantaged groups in accumulating "cultural capital" in the institutionalized state of educational qualifications (Bourdieu, 1997, p. 49). Therefore, knowledge is a saleable commodity that not everyone can buy. This is another reality that educational management levels must take into consideration in terms of public funding, privitalization, and scholarship programs for those under hardship.

\section{Conclusion}

The knowledge based economy is not the world's social trend anymore, but is a reality that countries have to confront in their strategic development. Education is of great significance because it directly contributes to a nation's economic growth in several ways such as improving the quality of the workforce, facilitating labor movements, enhancing the labor force's ability to absorb new information, breaking down social barriers to development, and encouraging entrepreneurship. Education has become a primary medium of globalization which generalizes the possible knowledge and skills for the global knowledge economy where the demands to generate new knowledge and to train human resource who know how to study lifelong are the necessities. In addition to producing and disseminating knowledge under the assistance of science and technologies, education is supposed to produce truly intellectual citizens who must be able to think critically and analytically for their professional lives. The new tasks are now upon education.

\section{References}

Abramovitz, M., \& David, P. A. (1996). Technological change and the rise of intangible investments. The US economy's growth-path in the twentieth century. Employment and growth in the knowledge-based economy (pp. 35-60). Paris: OECD.

Albrow, M., \& King, E. (1990). Globalization, knowledge and society. London: Sage.

Asia-Pacific Economic Cooperation (APEC). (2000). Towards knowledge-based economies. Singapore. Retrieved from http://www.apecsec.org.sg

Appadurai, A. (1996). Modernity at large: Cultural dimensions of globalization. Minneapolis: University of Minnesota Press.

Bao Вии dien Vietnam (2003). Retrieved from http://www.vnpost.mpt.gov.vn/bao_2003/so32/chuyende/t9b2.htm

Bennis, W., \& Nanus, B. (1985). Leaders. New York, NY: Harper and Row.

Bloom, B., Mesia, B. B., \& Krathwohl, D. R. (1964). Taxonomy of educational objectives. New York, NY: David McKay.

Bourdieu, P. (1997). The forms of capital. In A. H. Halsey, H. Lauder, P. Brown, \& A. S. 
Wells (Eds.), Education: Culture, economy, and society (pp. 46-58). New York, NY: Oxford University Press.

Burt, R. S. (1992). Structural holes: The social structure of competition. Cambridge, MA: Harvard University Press.

Burton-Jones, A. (1999). Knowledge capitalism: Business, work and learning in the new economy. New York, NY: Oxford University Press.

Castells, M. (1999). Flows, networks, and identities: A critical theory of the informational society. In M. Castells, R. Flecha, P. Freire, H. A. Giroux, D. Macedo, \& P. Willis (Eds.), Critical education in the new information age (pp. 37-64). Lanham, Oxford: Rowman \& Littlefield Publishers, Inc.

Castells, M. (2000). End of millennium ( ${ }^{\text {nd }}$ ed.). Massachusetts: Blackwell Publishers.

Christie, P., \& Lingard, R. (2001, April). Capturing complexity in educational leadership. Paper presented to the American Educational Research Association Conference, Seattle.

Christie, P., \& Sidhu, R. (2002). Responding to globalization: Refugees and the challenges facing Australian schools. Mots Pluriels, 21, May.

Do, D. D. (2003). Nhung co so ly thuyet, thuc tien va xu huong dieu chinh chinh sach kinh te doi ngoai o mot so nuoc chau A trong boi canh toan cau hoa va tu do hoa (Theoretical and practical bases and tendencies to regulate foreign economic policies in some Asian countries in the contexts of globalization and liberalization). Hanoi: The Gioi Publishing House.

Drucker, P. F. (1993). Post-capitalist society. New York, NY: Harper Bus.

Drucker, P. F. (1994). Post-capitalist society. Oxford: Butterworth-Heinemann.

Department of Trade and Industry (DTI). (1998). Our competitive future: Building the knowledge driven economy. London: DTI.

Duffy, F. M. (1997). Supervising schooling, not teachers. Educational Leadership, 54(8), 78-83.

Duong, N. (2009). Dan so Viet Nam qua cac thoi ky (Vietnam's population throughout the times). VNEconomy. Retrieved from http://vneconomy.vn/2009040210345706P5C11/dan-so-viet-nam-qua-cac-thoi-ky.htm

Educational Statistics. (2009). Ha Noi: Ministry of Education and Training, Mang Giao duc (Edu.Net). Retrieved from http://edu.net.vn/data/thongke/index.htm

Foucault, M. (1977). Discipline and punish: The birth of prison. New York, NY: Vintage Books.

Friedman, T. L. (2005). The world is flat. New York, NY: Farrar, Straus and Giroux.

Globalization Guide (2000). Retrieved from http://www.localization-translation.com/globalization-guide/localization-countries

Govindan, K. (2000, April). Globalization, k-economy, and the virtual space. Paper presented at the $12^{\text {th }}$ National Real Estate Conference, Kuala Lumpur, Malaysia.

Grant, R. M. (1996). Toward a knowledge-based theory of the firm. Strategic Management Journal, 17(Winter Special Issue), 109-122.

Held, D., McGrew, A., Goldblatt, D., \& Perraton, J. (2000). Rethinking globalization. In D. Held, \& A. McGrew (Eds.), The global transformation reader (pp. 14-20). Cambridge: 
Polity Press.

Houghton, J., \& Sheehan, P. (2000). A primer on the knowledge economy. Center for Strategic Economic Studies. Melbourne: Victoria University.

Iredale, R., Guo, F., \& Rozario, S. (2003). Introduction. In R. Iredale, F. Guo, \& Rozario, S. (Eds.), Return migration in the Asia Pacific (pp. 1-14). Cheltenham: Edward Elgar.

Jessop, B. (2007). Knowledge as a fictitious commodity: Insights and limits of a Polanyian perspective. In A. Bugra, \& K. Agartan (Eds.), Reading Karl Polanyi for the twenty-first century: Market economy as political project (pp. 115-133). New York, NY: Palgrave Macmillan.

Junge, D. A., Daniels, M. H., \& Karmos, J. S. (1984). Personnel managers' perceptions of requisite basic skills. The Vocational Guidance Quarterly, 33(2), 138-146.

Kirkbride, P. S., Durcan, J., \& Obeng, E. D. (1994). Change in a chaotic post-modern world. Journal of Strategic Change, 3(3), 151-163.

Kochan, T. A., \& Barley, S. R. (1999). The changing nature of work and its implications for occupational analysis. Washington DC: Natural Resource Council.

Lamberton, D. (1997). The knowledge-based economy: A Sisyphus model. Prometheus: Critical Studies in Innovation, 15(1), 73-81.

Law, S., \& Glover, D. (2000). Educational leadership and learning. Buckingham: Open University Press.

Limerick, D., Cunnington, B., \& Crowther, F. (1998). Managing the new organization: Collaboration and sustainability in the post-corporate world. New South Wales: Business and Professional Publishing.

Lin, B. C. (2006). A sustainable perspective on the knowledge economy: A critique of Austrian and mainstream views. Ecological Economics, 60(1), 324-332.

Lingard, B., Hayes, D., Mills, M., \& Christie, P. (2003). Leading learning. London; Philadelphia: Open University Press.

Linn, R. L., \& Gronlund, N. E. (1995). Measurement and assessment in teaching. New Jersey: Prentice Hall, Inc.

Lundvall, B., \& Johnson, B. (1994). The learning economy. Journal of Industry Studies, 1(2), 52-68.

Machlup, F. (1962). Knowledge and distribution of knowledge in the United States. New Jersey: Princeton University Press.

Marginson, S. (1999). After globalization: Emerging politics of education. Journal of Education Policy, 14(1), 19-31.

Marginson, S. (2004). Competition and markets in higher education: A glonacal analysis. Policy Futures in Education, 2(2), 175-244.

McFadyen, M. A., \& Cannella, A. A. (2004). Social capital and knowledge creation: Diminishing returns of the number and strength of exchange relationships. Academy of Management Journal, 47(5), 735-745.

Murphy, C., \& Jenks, L. (1983). Getting a job after college: What skills are needed? Journal of Career Education, 10(2), 80-93.

Nelson, R. R., \& Winter, S. G. (1982). An evolutionary theory of economic change. MA: Harvard University Press. 
Nguyen, C. H. (2010). The changing postmodern university. International Education Studies, 3(3), 88-99.

Nguyen, V. T. (2000, December). Vietnam and the issue of continuing higher education reform. Paper presented at the First International Forum on Education Reform, The University of Social Sciences and Humanities, Ho Chi Minh City, Vietnam. Retrieved from http://www.worldedreform.com/intercon/kedre16.htm

Nonaka, I., Toyama, R., \& Hirata, T. (2008). Managing flow: A process theory of the knowledge-based firm. Houndmills: Palgrave Macmillan.

Organization for Economic Cooperation and Development (OECD). (1996). The 1996 science, technology and industry outlook. Paris: OECD.

Organization for Economic Cooperation and Development (OECD). (2001). The knowledge-based economy. Paris: OECD.

Pham, H. V. (2006). Knowledge economy: A destination or a tool? Economic Studies. Retrieved from http://www.kinhtehoc.com/index.php?name=News\&file=article \&sid=246\&theme=Pri nter

Phan, D. D. (2000). Human capital (Von con nguoi). Sunday Youth (Tuoi Tre Chu Nhat), 50, 3-4.

Polanyi, M. (1966). The tacit dimension. New York, NY: Anchor Day Books.

Poverty Facts and Statistics. (2005). Retrieved from http://www.globalissues.org/article/26/poverty-facts-and-stats

Proenza, L. M. (2000). The challenges of globalization. Speech for UA Commencement. Ohio: The University of Akron. Retrieved from http://www.uakron.edu/president/commencement.php

Reich, R. (1991). The work of nations. New York, NY: Simon and Schuster.

Romer, P. M. (1986). Increasing returns and long-run growth. Journal of Political Economics, 94(5), 1002-1037.

Schon, D. (1995). The new scholarship requires a new epistemology. Change, 27(6), 27-34.

Schultz, T. W. (1963). The economic value of education. New York, NY: Columbia University Press.

Seltzer, K. (1996). A whole new way of learning. New Statesman, 44(56), 128-131.

Singapore's Ministry of Education. (2007). Mission and vision statement. Singapore: Ministry of Education. Retrieved from http://www3.moe.edu.sg/corporate/mission_statement.htm

Stevens, C. (1998). The knowledge-driven economy. In D. Neef (Ed.), The knowledge economy (pp. 87-94). Woburn, MA: Butterworth-Heinemann.

Straubhaar, T. (2001). Globalization, internal labor markets and the migration of the highly skilled. Intereconomics, (36)5, 221-22.

Thant, M. (1999). Lessons from East Asia: Financing human resource management. In R. Chew et al. (Eds.), Human capital formation as an engine of growth - The East Asian experience (pp. 203-236). Singapore: Institute of Southeast Asian Studies.

The State's Professorship Selection Board. (2010). Retrieved from http://www.hdcdgsnn.gov.vn/news/detail/tabid/77/newsid/258/seo/BAO-CAO-TONG- 
KET-DOT-XET-CONG-NHAN-DAT-TIEU-CHUAN-CHUC-DANH-GIAO-SU-PHO -GIAO-SU-NAM-2009/language/vi-VN/Default.aspx

Tomassini, M. (2001, January). Evolutionary perspectives on action methodologies for knowledge development and learning in organizations. Paper presented at the Conference HRD Research and Practice across Europe, The University of Twente, The Netherlands.

Tran, X. S. (2002). New characteristics of knowledge-based economy. Nature, Society, and Thought, 15(4), 469-481.

von Hayek, F. A. (1945). The use of knowledge in society. American Economic Review, (35)4, 519-530.

Walter, W. P., \& Snellman, K. (2004). The knowledge economy. Annual Review of Sociology, 30, 199-220. doi: 10.1146/annurev.soc.29.010202.100037.

Waters, M. (2001). Globalization ( $2^{\text {nd }}$ ed.). London: Routledge.

Yeung, H. W. (2001, October). Questioning the uneven terrains of economic globalization. Paper presented at the Conference on "Geographies of Global Economic Change" at the Graduate School of Geography, Clark University, USA. 